\title{
Service Quality as Drivers of Customer Loyalty and Intention to Switch: Modeling the Mediating Effect of Customer Satisfation
}

\author{
Zailin Zainal Ariffin ${ }^{1}$, Azizul Yadi Yaakop ${ }^{2}$, Norsuhada Isa ${ }^{3}$, Siti Sarah Omar ${ }^{4}$, Nor Khasimah Aliman ${ }^{5}$, Ramraini \\ Ali Hassan ${ }^{6}$
}

\author{
${ }^{1,3}$ Faculty of Defence Studies and Management, National Defence University of Malaysia \\ ${ }^{2}$ School of Maritime Business and Management, Universiti Malaysia Terengganu \\ ${ }^{4}$ Faculty of Technology Management and Business, Universiti Tun Hussein Onn Malaysia \\ ${ }^{5}$ Faculty of Business and Management, UiTM Perak, Seri Iskandar Campus \\ ${ }^{6}$ Faculty of Business, Economics and Accountancy, Universiti Malaysia Sabah \\ *Corresponding authorE-mail: zailin@upnm.edu.my; azizul_yadi@umt.edu.my
}

\begin{abstract}
The following study examines relationship of service quality, customer satisfaction, customer loyalty and consumers' intentions to switch among finance and insurances consumers in Klang Valley area. Although many researchers have studied of service quality, customer satisfaction, customer loyalty and intention to switch, limited studies explore customer satisfaction as mediating role in the model. The present study proposes SERVQUAL model as indicator to determine the customer satisfaction among finance and insurances consumer. Stratified random sampling technique will be employed in the present study. Data collected also will be analyzed using the Smart PLS (Partial Least Square) to answer the hypothesis. It is believed that the mediating role of customer satisfaction is a promising area to explore and the potential to provide significant benefit to the finance and insurance institution.
\end{abstract}

Keywords: Customer Satisfaction; Customer Loyalty; Intention To Switch; Servqual Model; Service Quality

\section{Introduction}

Financial and insurance institutions worldwide are re-constructing their plan of actions to meet new challenges in order to remain strategic, competitive and profitable in the market (1) (2-4). In the highly competitive corporate environment, quality of services is of paramount important for customer satisfaction and customer loyalty (5). In today's dynamic corporate environment, customer satisfaction is the key element for a successful business venture. As a matter of fact, customer satisfaction has been empirically proven to greatly influence customers' repurchase intentions whereas dissatisfaction has been seen as a primary reason for customer's intentions to switch (6). Customer loyalty is not a new research area and some researcher has studied factors leading to customer loyalty, such as service quality provide, customer satisfaction, customers trust and switching barriers. Nevertheless, the integrated framework on the mediating effect of customer satisfaction between the relationship of service quality, customer loyalty and intention to switch in Malaysia's specific sector has not been discussed extensively before. Further investigation on the mediating effect of customer satisfaction towards the relationship of service quality, customer loyalty and intention to switch will be discussed in this present research. SERVQUAL model will be used as rater for service quality framework to measure the scale of quantity in the propose framework.

The main aim of the present study is to build an integrated conceptual framework in examine the mediating effect of customer satisfaction using SERVQUAL model towards customer loyalty and intention to switch among finance and insurance consumers in highly populated area of Klang Valley, Malaysia (Department of Statistic Malaysia, 2015). The conceptual study is expected to facilitate the practitioner in formulating new strategies and academician in contributing new idea to the body of literature.

\section{Literature Review}

There are numbers of definitions of service quality by different researcher. First, in research "Strategic analysis of healthcare service quality using fuzzy AHP methodology. Expert Systems with Applications", Büyüközkan et al.,(7) states that service quality is defined as the difference between customer expectations of service and perceived service. Another researcher, Kritikos et al.,(8), refer service quality as a set of nonfunctional attributes in the interaction between service and customer that include, inter alia, the service and the customer, that signify the service ability to satisfy needs in the research "A survey on Service Quality description". Ye et al.,(9), in the research "The Influence Of Hotel Price On Perceived Service Quality And Value In E-Tourism: An Empirical investigation Based On Online Traveler Reviews" state service quality means the ability to meet customers' stated and implied needs. Another scholar, Melaku (10) in the research "Impact of Service Quality on Customer Satisfaction: The Case of Bank of Abyssinia" state service is intangible in nature, it cannot be mass produced. It cannot be inventoried and store after production. Due to the fact that services and consumers of services are inseparable, they cannot be produced until the consumer is ready to consume them.

Auka et al.,(11), stated that service quality is the total appraisal of overall service delivery quality, which resulted from the compari- 
son that consumers make between their overall expectations about a service and their perceptions of the way the service was performed or delivered. Generally, customers compare the perceived performance of a product with a performance standard. In an occurrence where the perceived performance is greater than the standard (positively disconfirmed); customers are satisfied. On the other hand, when the performance falls short of the standard (negatively disconfirmed); customers are dissatisfied. Like many other industries, customer satisfaction is one of the most important issues concerning in finance and insurance industry.

To evaluate service quality, SERVQUAL model was used as indicator in service quality framework. It is also used to measure the scale of quality in service sector. The theoretical framework by Parasuraman et al.,(12), has identify determinants and elements of service quality. This is also supported by Ravichandran et al.,(13), by stated that SERVQUAL model was a rater to evaluated customer satisfaction in banking industry. The original SERVQUAL model was firstly started with 10 original dimensions(14).

After several research of SERVQUAL conducted in this field, the SERVQUAL variable have finally confirmed with five dimensions, i.e., tangibility, reliability, responsiveness, assurance and empathy (15). For the purpose of current study, SERVQUAL model was adapted to determine the dimensions of service quality construct among finance and insurance company in Klang Valley, Malaysia. Many researcher adopt the definition from the original SERVQUAL dimension by (12). From 10 dimensions stated, only 5 dimension uses as indicator of SERVQUAL dimension after several studies of researcher $(16,17)$.

Customer satisfaction is a term frequently used in service quality measurement. There are many previous research was define customer satisfaction in their literature review. According to Arokiasamy (18), in research "The impact of customer satisfaction on customer loyalty and intentions to switch in the banking sector in Malaysia”, customer satisfaction is one of the most fundamental issues concerning business organizations, in parallel with the customer oriented philosophy and the principles of continues improvement in modern enterprise. Mittal et al.,(19), define customer satisfaction as customer's post-consumption evaluation of a product or service. Another researcher, Tse et al.,(20), defined customer satisfaction as "The customer's response to the evaluation of the perceived discrepancy between prior expectations and the actual performance of the product/service as perceived after its consumption. In the studies "Relative Importance of Perceived Value, Satisfaction and Perceived Risk on Willingness to Pay More" by Demirgüneş (21), customer satisfaction was defined as the product is a person's feelings of pleasure or disappointment resulting from comparing a product's perceived performance in relation to his/her expectation

The definition of customer loyalty was derived by a several scholar in previous studies. In research "Impact of Service Quality on Customer Satisfaction and Customer Loyalty: Evidence from Banking Sector". Khan et al., (5), define customer loyalty as a feeling of association which a customer has towards a brand. He added that this feeling incites customer for acquiring a good or service repeatedly. Another researcher Selness (22), define customer loyalty as an intended behavior related to the product or service. This includes the likelihood of future purchases or renewal of service contracts or, conversely, how likely it is that the customer will switch to another brand or service provider. According to Chen (23), in the research "Customer value and customer loyalty: Is competition a missing link?" customer loyalty defined as a consumer's loyal attitude and behavior toward a specific service firm, despite competitors providing alternative services in the market.

There are many definition of intention to switch was defined by different authors. Jabeen et al., (24), in the research "Switching Intentions: A Case of Saudi Arabian Hypermarkets" state switching intention is the signal of termination of customer's relationship with current service provider partially or fully related to consumer switching. According to Bansal et al., (25), in research of "Migrat- ing to new service providers: Toward a unifying framework of consumers' switching behaviors" state switching intention as migration model from the human geography literature to examine push, pull and mooring variables in service switching. Another researcher, Amin et al., (26), in research "Hospital service quality and its effects on patient satisfaction and behavioral intention" define intention to switch as behavioral intention as a signal of whether customers will remain or exit the relationship with the service provider.

\subsection{Linkages between Variables}

\subsubsection{Service Quality and Customer Satisfaction}

Despite the importance of relating the service quality and customer satisfaction, many researcher state that high impact of service quality give influence to high customer satisfaction. A scholar supported the argument earlier, Kazemi, et al.,(27), state that there is a positive and significant impact of hospital service quality on patient satisfaction. In addition, other hypothesis was tested and there was a positive and significant relationship between hospital service quality and five dimensions. Another research, Ilyas, et al., (28), in state the banking institutions are exceeding customer expectations in three dimensions i.e. "Tangibles", "Reliability" and "Responsiveness" and lacking other two dimensions "Assurance" and "Empathy". The main reason behind this satisfaction is high level of competition among the banks in Pakistan and another reason might be the strong regulatory framework of banks in Pakistan. According to Shagari, et al.,(29), found that a linear positive relationship exists between customer satisfaction level and customer care service at General System Mobile Communication (GSM) services.

\subsection{Customer Satisfaction and Customer Loyalty}

Customer who satisfied with service provide has a relationship with customer loyalty. Based on previous studies, Flint, et al.,(30), found customer satisfaction positively affects customer loyalty in their research connections between suppliers and customers at manufacture industry(31). Another researcher, Siddiqi, et al., (32), show that there a positive correlation between customer satisfaction and customer loyalty in the retail banking in their paper. Another studies by Daikh (33), argues that customer loyalty and customer satisfaction are indeed positively related. Having said that, industry players need to fully aware that the loyalty is very hard to achieve and is not very easy to be reached by industries. This is due both element of customer satisfaction as well as service quality, which are realistic but sometimes may be very stringent.

\subsection{Customer Satisfaction and Intention to Switch}

High level satisfaction will give lower impact to intention to switch. Customer satisfaction give influence toward intention to switch. Based on past studies, Arokiasamy (18), state there is a significant negative relationship between intentions to switch and customer satisfaction in banking retail at Malaysia. Another researcher, Gall, et al., (34), found the greatest predictors of switching behavior was a combination of attitude towards switching and banking customer. According to Martins, et al., (35), shows switching barriers, service performance, and perceived value in carriers' offers, satisfaction and other constructs can play a pivotal role in customer switching processes among carriers in their research.

\subsection{Mediating Effect of Customer Satisfaction}

\section{Service Quality and Customer Loyalty}

Service quality has strong relationship with customer loyalty and use customer satisfaction as mediating. There are many studies 
conduct to analyze this relationship. According to Osman et al., (36), customer satisfaction have significant and positive partial mediating effect on service quality and customer loyalty relationship in Malaysia rural tourism. Besides that, the study by Srivastava, et al.,(37), customer satisfaction as an intervening variable that offers directional influence as a mediator of the relationship between service quality and customer loyalty in the life insurance industry at India. Past researcher, Hussain (38), shows the mediating effect of customer satisfaction between service quality and brand loyalty in airlines industry. Further, customer satisfaction is studied as a significant mediator between brand trust, and brand loyalty (39). It was to show that the impact of service quality on brand loyalty was significantly different (higher) from the impact of service quality on brand loyalty when customer satisfaction was controlled. The conclusion is that customer satisfaction plays a mediating role in the relationship between service quality and customer loyalty.

\section{Service Quality and Intention to Switch}

There is a mediating relationship between service quality, intention to switch and customer satisfaction. It is hypothesized that high service quality provided to customer leads to high customer satisfaction, which in turn will reduce their intention to switch According to Bansal et al.,(40), service satisfaction has been identified as a mediator of service quality and is potentially an important determinant of service switching. Furthermore, Anton et al.,(41), found substandard service quality and deficient in firm commitment weaken customer satisfaction and these will affect organizations badly, directly and indirectly through customer dissatisfaction, in terms of switching intentions, price unfairness and anger incidents.

\subsection{Conceptual Framework}

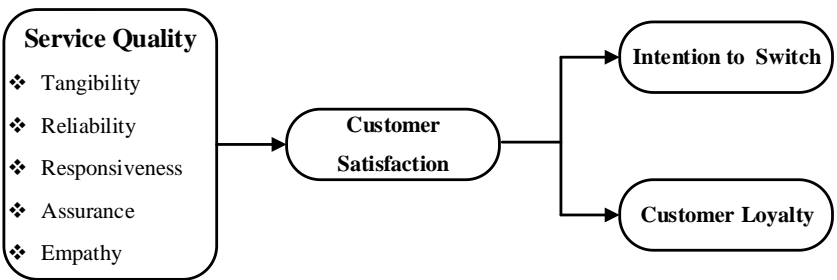

Fig. 1: Conceptual framework

\subsection{Research Hypothesis}

Based on the conceptual framework above, there are several hypotheses that can be made:

H1: Service quality for finance and insurances has positive impact toward customer satisfaction.

$\mathrm{H} 2$ : There is a significant positive relationship between customer satisfaction and customer loyalty.

H3: There is a significant negative relationship between customer satisfaction and intentions to switch.

\section{Methodology}

\subsection{Sampling Techniques and Data Collection}

For "Modelling the Mediating Effect of Customer Satisfaction between the relationship of Service Quality, Customer Loyalty and Intention to Switch" research, data will collect through a structured questionnaire survey. Data collection is a process of gathering information and it is a pivotal stage in a research study (42). A survey will employ as the main method of data collection using a structured form of questionnaire distributed to selected consumers. Non-probability sampling method will use to conduct these studies. Stratified random sampling applied in this study based on demographic include gender, race, age, marital status, occupation, job position, household income and highest education level of respondent. Proportional quota sampling has been used based on the percentage revealed by Department of Statistic Malaysia (Department of Statistics Malaysia, 2015). After conducting this study, data collected will be analyze using the Smart PLS (Partial Least Square) to answer the hypothesis.

\subsection{Measurement of Construct}

The measurement for SERVQUAL dimension, customer satisfaction, customer loyalty and intention to switch research as shown in table below. This several questionnaire assessed all variables of conceptual model. As mentioned earlier, all construct in this study were measured using 5 Likert scale ranging from (1) "strongly disagree", to (5)"strongly agree".

Table 1: Measurement of Construct for Independent and DEpendent Variables

\begin{tabular}{|c|c|}
\hline Modified items & Sources \\
\hline Service Quality & \\
\hline Tangibility Dimension & \\
\hline My finance and insurance outlet are clean. & \\
\hline $\begin{array}{l}\text { My finance and insurance company has provide a great } \\
\text { details and information about their products. }\end{array}$ & \\
\hline Employees at service counter are neat in appearance. & (43) \\
\hline $\begin{array}{l}\text { My finance and insurance using a modern looking equip- } \\
\text { ment. }\end{array}$ & \\
\hline Service area has a great decoration. & (44) \\
\hline Service area is flexible to customer. & \\
\hline Reliability Dimension & \\
\hline $\begin{array}{l}\text { My finance and insurance company provided their services } \\
\text { promises at the time. }\end{array}$ & $(45)$ \\
\hline $\begin{array}{l}\text { When I have a problem with service provided, the employ- } \\
\text { ee show interest to solve my problem. }\end{array}$ & (44) \\
\hline $\begin{array}{l}\text { Finance and insurances company will has an accurate rec- } \\
\text { ord. }\end{array}$ & \\
\hline I can easily reach to the service. & \\
\hline The retail has a flexible time to reach. & \\
\hline Responsiveness Dimension & \\
\hline $\begin{array}{l}\text { Finance and insurances company will take action immedi- } \\
\text { ately when I make complain. }\end{array}$ & \\
\hline $\begin{array}{l}\text { The employees will inform me about their services per- } \\
\text { formed. }\end{array}$ & \\
\hline $\begin{array}{l}\text { Insurance company give me clearly description about their } \\
\text { packages. }\end{array}$ & (46) \\
\hline $\begin{array}{l}\text { Customer service of finance and insurance company pro- } \\
\text { vide me a quick services. }\end{array}$ & (44) \\
\hline $\begin{array}{l}\text { Customer service of insurance company always willing to } \\
\text { assist me as their customers. }\end{array}$ & \\
\hline $\begin{array}{l}\text { Customer service of finance and insurance company al- } \\
\text { ways able to respond my request. } \\
\text { Assurance Dimension }\end{array}$ & \\
\hline $\begin{array}{l}\text { Employees of finance and insurances company show a lot } \\
\text { of knowledge and information about their service provided } \\
\text { to me. }\end{array}$ & \\
\hline $\begin{array}{l}\text { Customer service of finance and insurance company able to } \\
\text { settle my problem with satisfactory. }\end{array}$ & (44) \\
\hline $\begin{array}{l}\text { Employees of finance and insurance company give good } \\
\text { service for their customer with smile. }\end{array}$ & \\
\hline $\begin{array}{l}\text { Employee of finance and insurance company always give } \\
\text { their service with courtesy. }\end{array}$ & $(45)$ \\
\hline I feel safe with their insurar & \\
\hline $\begin{array}{l}\text { The behavior of finance and insurance company give me a } \\
\text { confident to deal }\end{array}$ & (44) \\
\hline Emphaty Dimension & \\
\hline $\begin{array}{l}\text { Customer service of finance and insurance company gives } \\
\text { me individual attention. }\end{array}$ & \\
\hline $\begin{array}{l}\text { Operating hours of finance and insurance company are } \\
\text { flexible to customer. }\end{array}$ & (43) \\
\hline $\begin{array}{l}\text { Finance and Insurances company give me the best interest } \\
\text { at heart to attract customer. }\end{array}$ & \\
\hline $\begin{array}{l}\text { I get personal attention during dealing with finance and } \\
\text { insurance company employees. }\end{array}$ & \\
\hline Customer service of finance and insurance company under- & \\
\hline
\end{tabular}




Modified items
Customer Satisfaction
Overall, finance and insurances companies has provided a
good service quality to me.
I'm satisfied toward their service provide.
I will using the finance and insurances company service
continuously.
I will recommend and tell others people about the service
provide.
I'm attracted toward employees act during service provide.
Their service are up to my expectation.
Customer Loyalty
I think I'm loyal to a particular finance and insurance com-
pany.
I have loyalty card for my finance and insurance company.
I prefer the service of my finance and insurance companies
compare to the service of competitors.
I think this institution will be my prefered finance and
insurance company.
I am willing to repurchase the same kind of services pro-
vide by this finance and insurance company.
Intention to Switch
I intend to switch to another finance and insurance compa-
ny.
I need service from another finance and insurance compa-
ny.
I would like to stop all the service from my current finance
and insurance company.
People who influence my behavior would approve me to
switching from my current finance and insurance company.
I to put much effort in deciding which other finance and
insurance company to deal with

\section{Conclusion}

In sum, this current study supported past literature linkages between service quality, customer satisfaction, customer loyalty and intention to switch $(18,29,33)$. In addition, this conceptual paper offers the usage expansion of SERVQUAL model in design and improvement of quality services. The researchers also proposed the integrated conceptual structure on the mediating effect of customer satisfaction between the relationship of service quality, customer loyalty and intention to switch in specific sector in Malaysia. Even though, the paper is mostly hypothetical, it is inspiring to reveal an integrated conceptual framework in exploring customer satisfaction as mediating role. Facing more sophisticated consumers' needs and challenged by more aggressive competitors, the practitioners may use this proposed framework in strategizing their business model.

\section{Reference}

[1] 1. Malik SA, Nasim K, Iqbal MZ. TQM practices in electric fan manufacturing industry of Pakistan. International Journal of Productivity and Quality Management. 2013;12(4):361-78.

[2] 2. Hossain M, Leo S. Customer perception on service quality in retail banking in Middle East: the case of Qatar. International Journal of Islamic and Middle Eastern Finance and Management. 2009;2(4):338-50

[3] 3. Ghost FH, Gnanadhas M. Impact of service quality in commercial banks on the customer's satisfaction: An empirical study. International Journal of Multidisciplinary Research. 2011:1(6):19-37.

[4] 4. Narteh B, Owusu-Frimpong N. An analysis of students' knowledge and choice criteria in retail bank selection in subSaharan Africa: The case of Ghana. International Journal of Bank Marketing. 2011;29(5):373-97.

[5] 5. Khan MM, Fasih M. Impact of Service Quality on Customer Satisfaction and Customer Loyalty: Evidence from Banking Sector. Pakistan Journal of Commerce \& Social Sciences. 2014;8(2).

[6] 6. Mohsan F, Nawaz MM, Khan MS, Shaukat Z, Aslam N Impact of customer satisfaction on customer loyalty and intentions to switch: Evidence from banking sector of Pakistan. International Journal of Business and Social Science. 2011;2(16).
[7] 7. Büyüközkan G, Çifçi G, Güleryüz S. Strategic analysis of healthcare service quality using fuzzy AHP methodology. Expert systems with applications. 2011;38(8):9407-24.

[8] 8. Kritikos K, Pernici B, Plebani P, Cappiello C, Comuzzi M, Benrernou $\mathrm{S}$, et al. A survey on service quality description. ACM Computing Surveys (CSUR). 2013;46(1):1.

[9] 9. Ye Q, Li H, Wang Z, Law R. The influence of hotel price on perceived service quality and value in e-tourism: an empirical investigation based on online traveler reviews. Journal of Hospitality \& Tourism Research. 2014;38(1):23-39.

[10] 10. Melaku M. Impact of Service Quality on Customer Satisfaction: The Case of Bank of Abyssinia SC: Addis Ababa University; 2015

[11]11. Auka D, Bosire JN, Matern V. Perceived service quality and customer loyalty in retail banking in Kenya. 2013.

[12] 12. Zeithaml VA, Berry LL, Parasuraman A. The behavioral consequences of service quality. the Journal of Marketing. 1996:3146.

[13] 13. Krishnamurthy R, SivaKumar MAK, Sellamuthu P. Influence of service quality on customer satisfaction: Application of SERVQUAL model. International Journal of Business and Management. 2010;5(4):117.

[14] 14. Arch J. The brown adipocyte $\beta$-adrenoceptor. Proceedings of the Nutrition Society. 1989;48(2):215-23.

[15] 15. Yarımoğlu K. Emel,(2014), A Review on Dimensions of Service Quality Models. Journal of Marketing Management.2(2):79-93.

[16]16. Dawi NM, Jusoh A, Nor KM, Qureshi MI. Service Quality Dimensions in Pay TV Industry: A Preliminary Study. International Review of Management and Marketing. 2016;6(4S).

[17] 17. Qureshi MI, Khan A, Zaman K, Khaqan N. Structural investigation of service quality in conventional and islamic banking in pakistan. International Journal of Management and Innovation. 2014;6(1):84.

[18] 18. Arokiasamy ARA. The impact of customer satisfaction on customer loyalty and intentions to switch in the banking sector in Malaysia. The journal of commerce. 2013;5(1):14-21.

[19]19. Mittal V, Kamakura WA. Satisfaction, repurchase intent, and repurchase behavior: Investigating the moderating effect of customer characteristics. Journal of marketing research. 2001;38(1):131-42

[20]20. Tse DK, Wilton PC. Models of consumer satisfaction formation: An extension. Journal of marketing research. 1988:20412 .

[21]21. Demirgünescedil BK. Relative Importance of Perceived Value, Satisfaction and Perceived Risk on Willingness to Pay More. International Review of Management and Marketing. 2015;5(4).

[22]22. Selnes F. An examination of the effect of product performance on brand reputation, satisfaction and loyalty. European Journal of marketing. 1993;27(9):19-35.

[23]23. Chen S-C. Customer value and customer loyalty: Is competition a missing link? Journal of Retailing and Consumer Services. 2015;22:107-16.

[24]24. Jabeen S, Hamid ABA, Rehman SU. Switching Intentions: A Case of Saudi Arabian Hypermarkets. International Journal of Economics and Financial Issues. 2015;5(1S).

[25]25. Bansal HS, Taylor SF, St. James Y. "Migrating" to new service providers: Toward a unifying framework of consumers' switching behaviors. Journal of the Academy of Marketing Science. 2005;33(1):96-115

[26]26. Amin M, Zahora Nasharuddin S. Hospital service quality and its effects on patient satisfaction and behavioural intention. Clinical Governance: An International Journal. 2013;18(3):238-54

[27]27. Kazemi N, Ehsani P, Abdi F, Bighami M. Measuring hospital service quality and its influence on patient satisfaction: An empirical study using structural equation modeling. Management Science Letters. 2013;3(7):2125-36

[28]28. Ilyas A, Nasir H, Malik MR, Mirza UE, Munir S, Sajid A. Assessing the service quality of Bank using SERVQUAL model. Interdisciplinary journal of contemporary research in business. 2013;4(11):390-400.

[29]29. Shagari JN, Abubakar A. Appraisal of Customer Satisfaction with GSM Services in Dutsin-Ma, Katsina State, Nigeria.

[30]30. Flint DJ, Blocker CP, Boutin PJ. Customer value anticipation, customer satisfaction and loyalty: An empirical examination. Industrial marketing management. 2011;40(2):219-30. 
[31]31. Shah SHA, Gul S, Shakir H, Qureshi I. Switching cost and consumer behaviour: A structural analysis of telecom sector of Pakistan. World Applied Sciences Journal. 2013;28(4):513-27.

[32]32. Siddiqi KO. Interrelations between service quality attributes, customer satisfaction and customer loyalty in the retail banking sector in Bangladesh. International Journal of Business and Management. 2011;6(3):12.

[33]33. Daikh J. A Research Proposal: The Relationship between Customer Satisfaction and Consumer Loyalty. 2015.

[34]34. Olsson F, Gall G. How do the predictors of switching intention influence switching behavior?: A quantitative study of students' switching behavior in the retail banking context. 2012.

[35]35. Martins RC, Hor-Meyll LF, Ferreira JB. Factors affecting mobile users' switching intentions: A comparative study between the Brazilian and German markets. BAR-Brazilian Administration Review. 2013;10(3):239-62.

[36] 36. Osman Z, Sentosa I. Mediating effect of customer satisfaction on service quality and customer loyalty relationship in Malaysian rural tourism. 2013.

[37] 37. Srivastava K, Sharma NK. Service quality, corporate brand image, and switching behavior: The mediating role of customer satisfaction and repurchase intention. Services Marketing Quarterly. 2013;34(4):274-91.

[38]38. Hussain R. The mediating role of customer satisfaction: evidence from the airline industry. Asia Pacific Journal of Marketing and Logistics. 2016;28(2):234-55.

[39] 39. Umar A, Bahrun R. The Mediating Relationship of Customer Satisfaction Between Brand Trust, Brand Social Responsibility Image with Moderating Role of Switching Cost. Advanced Science Letters. 2017;23(9):9020-5.

[40]40. Bansal HS, Taylor S, editors. Investigating the relationship between service quality, satisfaction and switching intentions. Proceedings of the 1997 Academy of Marketing Science (AMS) Annual Conference; 2015: Springer.

[41]41. Antón C, Camarero C, Carrero M. The mediating effect of satisfaction on consumers' switching intention. Psychology \& Marketing. 2007;24(6):511-38.

[42]42. Zikmund WG, Babin BJ, Carr JC, Griffin M. Business research methods: Cengage Learning; 2013.

[43]43. Chingang Nde D, Lukong P. Using the SERVQUAL Model to assess Service Quality and Customer Satisfaction.: An Empirical Study of Grocery Stores in Umeå. 2010.

[44]44. Gibson C. Using SERVQUAL to assess the customer satisfaction level of the Oregon HIDTA ISC analytical unit. Hatfield School of Government. 2009.

[45]45. Lau MM, Cheung R, Lam AY, Chu YT. Measuring service quality in the banking industry: a Hong Kong based study. Contemporary Management Research. 2013;9(3):263.

[46]46. Benbernou S, Ivona B, Nitto D, Carro M, Kritikos K, Parkins M. A survey on service quality description. ACM Computing Survey V. 2009:1-77.

[47]47. Krishnamurthy A. How debt markets have malfunctioned in the crisis. The Journal of Economic Perspectives. 2010;24(1):3-28.

[48]48. Smith G, Smith A, Clarke A. Evaluating service quality in universities: a service department perspective. Quality assurance in education. 2007;15(3):334-51.

[49]49. de Jong S. Customer Satisfaction and Customer Loyalty Among Grocery Shoppers a Research Done in The Netherlands: Erasmus University; 2011.

[50]50. Hallowell R. The relationships of customer satisfaction, customer loyalty, and profitability: an empirical study. International journal of service industry management. 1996;7(4):27-42.

[51] 51. Murad MMM. Direct and moderating factors affecting customer switching intentions: An empirical study on bank of Palestine and Cairo Amman Bank in Gaza Strip: The Islamic University-Gaza; 2011. 